\title{
Gap Analysis and Measurement of Information Technology Readiness for Improvement of Competitive Capabilities to Small and Medium Enterprises in East Java
}

\section{Tri Andjarwati ${ }^{1}$, Agus Hermanto ${ }^{2}$, and Supangat²}

1Economic Departement, Universitas 17 Agustus 1945, Jl. Semolowaru 45, Surabaya 60119, Indonesia

${ }^{2}$ Informatics Departement, Universitas 17 Agustus 1945, Jl. Semolowaru 45, Surabaya 60119, Indonesia

\section{Abstract}

The growing development of SME sector can be a benchmark for the great potential in improving the economy in East Java. The potential of SMEs will be able to realize

Corresponding Author:

Tri Andjarwati

triandjarwati@untag-sby.ac.id

Received: 7 August 2018

Accepted: 15 September 2018

Published: 22 October 2018

Publishing services provided by

Knowledge $\mathrm{E}$

(c) Tri Andjarwati et al. This article is distributed under the

terms of the Creative Commons

Attribution License, which

permits unrestricted use and

redistribution provided that the

original author and source are credited.

Selection and Peer-review under the responsibility of the ICE-BEES 2018 Conference Committee. a tough and small business, if managed and developed properly. Meanwhile, on the other hand SMEs are also still faced with the problems that lies in the process of administrative and management by utilizing information and communication technology (ICT), thus becoming an obstacle in the development of its business.

While at present, for business owners who want to develop their business and able to survive in the competition, one of the efforts that can be done is by utilizing information and communication technology (ICT) as well as having good management capability in managing company's operational.

Therefore, in this study, we conducted a gap analysis and measurement of information technology readiness for SMEs as a way to improve competitive ability. In this research, the method of measuring the level of maturity that we use is BPMM (business process maturity model) and CMMI for SMEs in eastern Java. Based on these measurements, we have also made recommendations for gap improvement in the form of recommendation that can be used by SME owners in improving their organizational skills.

It is expected that with the availability of improved forms of organization maturity level can help the competitive ability of existing SMEs in eastern Java in order to continue to grow and it has the ability of continuous improvement.

Keywords: Maturity Model, SME, IT Readiness, BPMM

\section{G OPEN ACCESS}




\section{Introduction}

The development and growth of small and medium enterprises (SMEs) is one of the driving forces of economic growth, which comes from the family / home industry. Thus, consumers also come from the middle to lower class. In addition, the role of SMEs especially since the monetary crisis in 1998 can be viewed as a rescue valve in the process of national economic recovery, both in encouraging the rate of economic growth and employment, especially in East Java.

Based on data from the Office of Cooperatives and SMEs of East Java Province, Small and Medium Enterprises (SMEs) sector becomes the key of economic growth in East Java. In the midst of the economic crisis that is still volatile, East Java still has a conducive economy supported by SMEs. The contribution of SMEs can be seen from the high contribution of SMEs to East Java GRDP reaches around IDR 900 trillion from January to August 2016 [1]. East Java Province has approximately 6.81 million SME entrepreneurs with turnover of Rp3o billion per year, with details of 95.71 percent or 6.50 million micro businesses, as many as 250 thousands or 3.84 percent small businesses, and 0.45 percent or 50 thousand medium enterprises, with the ability to absorb the workforce of 11.12 million people (as shown in table 1 below) [1].

The rapid development of the SME sector shows that there is great potential if it can be managed and developed properly which will certainly be able to realize a tough middle business. Meanwhile, on the other hand, SMEs are still faced with problems that lie in the administrative and management processes by utilizing information and communication technology (ICT) devices, resulting in difficulty for improving performance, access to wider markets, and producing performance reports business and finance as a condition to obtain credit or additional capital. Therefore, in this study we measured the level of information technology readiness and gap analysis to find out the current performance condition of SME and hope to be achieved. We also create a milestone plan that can be used as a step to improve the performance of SMEs in order to increase their productivity and competitiveness for competing in the market.

The explanation of this research is divided into four parts, the first part is the introduction (which discusses the development of SMEs in East Java and the problems faced), and the second part discusses the theoretical background relating to the level of organization maturity referring to BPMM and CMMI. While the third part, we discussed the research methodology we used and the last part is the conclusion obtained from the research results. 
TABle 1: Composition SMEs in East Java by Sector [1].

No
1
2
3
4
5
6
7
8
9
10

Sector
agriculture
mining and quarrying
processing industry
electricity, gas and water
Construction
Trade, Hotels And Restaurants
Transportation
Finance
Services
Total Amount

Numbers

$4,112,443$

26,680

356,047

12

16,789

$1,720,042$

174,541

8,035

411,342

$6,825,931$

\section{Theoretical Background}

\subsection{Business process evaluation}

Information technology has brought a great impact in the business world. Many companies are now competing in applying Information Technology to their entire business processes, as a way to optimize the company's performance in order to compete optimally with its competitors. An effort to improve the performance of the company can be done by evaluating the business processes that have attracted the attention of business owners and academics for a long time [2-4]. Existing challenges include applying process principles into company operations, using several means, including total quality management, continuous process improvement, and business process reengineering to improve business process orientation (BPO) $[5,6]$, particularly with respect to current conditions with a dynamically developing market environment with high uncertainty elements for the organization. Process management is an important factor for the organization's functioning and its positive impact on the success of organizational management [7]. Improving business processes is a key need to maintain the competitiveness of national business entities in global markets. Therefore, it can be stated that Business process management is a comprehensive way to implement efficient and effective business processes within an economic entity.

In conjunction with the process of evaluating business processes and organizational performance, this study focuses on a higher level of BPM, i.e. business performance management, with the aim of assessing the level of organization maturity, called maturity of business process management. The results obtained from several studies indicate that there is a positive correlation between business process management 
and organizational success, so it becomes a constant important motivation to advance the maturity of an organization's process.

The maturity model provides a process understanding capability for the organization and standard setting in process measurement and the introduction of possible improvements. The modeling tools are used for assessment as well as guidance for enhancing process capability [8]. The process of maturity also shows the form of perception of the process in accordance with the organization's strategy. On the one hand, the maturity of the process tells how to realize employees to participate in business processes, while on the other hand it can provide assistance for managers to use knowledge of processes in decision making and organizational development, while the meaning of the process of maturity is the management capability in managing and controlling the process effectively and measurably consistently to be applied into the organization [9]. The maturity level of the process can be seen from the level of organizational ability obtained from the transformation of one or more domains of an organizational process [10]. According to BPM handbook BPM maturity level is divided into five levels of maturity [11] as seen in Figure 1, namely:

1. Level 1: Initial and uncertainty - wherein business processes concept are more project ad hoc and chaotic, performed in inconsistent, sometimes ad hoc ways, with results that are difficult to predict;

2. Level 2: Repeated and Standardized - wherein small-scale business process concept are understood and repeatable in projects or management stabilizes the work within local work units to ensure that it can be performed in a repeatable way that satisfies the workgroup's primary commitments. However, work units performing similar tasks may use different procedures;

3. Level 3: Defined and Awakening - wherein business process concepts are documented and standardized across organization, or standard processes are synthesized from best practices identified in the work groups and tailoring guidelines are provided for supporting different business needs. Standard processes provide an economy of scale and a foundation for learning from common measures and experience;

4. Level 4: Managed And Enlightenment (Predictable) - wherein business process concepts are measured and controlled, or the capabilities enabled by standard processes are exploited and provided back into the work units. Process performance is managed statistically throughout the workflow to understand and control variation so that process outcomes can be predicted from intermediate states; 
5. Level 5: Optimized And Continuous Improvement (Innovating) - wherein continuous business process improvement via feedback and collaboration, or both proactive and opportunistic improvement actions seek innovations that can close gaps between the organization's current capability and the capability required to achieve its business objectives.

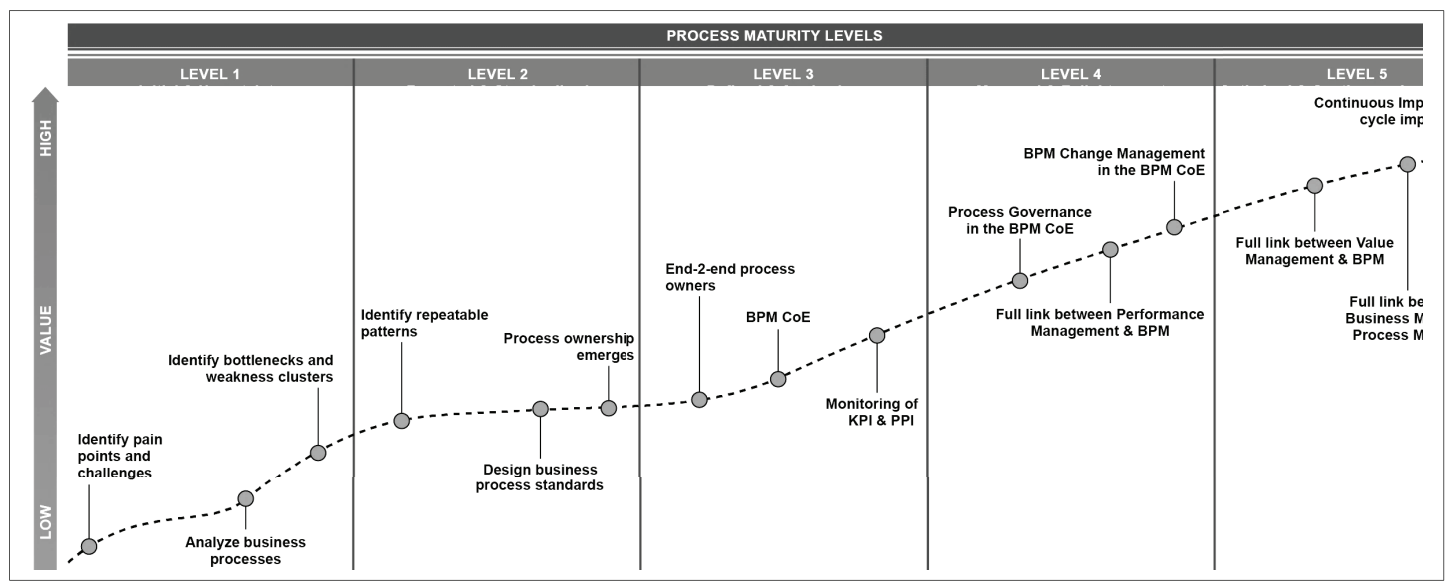

Figure 1: BPM Maturity Level and Examples Milestone of Improvement [11].

Based on the illustration of Figure 1, it can be explained that each step of improving the maturity level of an organization cannot be passed through the stages in each level to go directly to the higher level, because each of the mentioned process areas is designed to achieve specific goals in creating, or maintaining the characteristics of the organization's condition from that level [12].

Fulfilling the requirements of the process area from the maturity model and achieving the maturity level is a clear strategy for improving organizational processes and generating many benefits, as described previously, although not a direct indicator of the performance or achievement of business results [13]. The changes in the process of maturity models can improve business performance, but there are other factors that can also improve business performance, such as the development and management of labor, the use of technology, and the improvement of the organization's business strategy.

\subsection{The usage of information technology}

This section is used to summarize the existing literature on factors related to IT adoption, a factor that is crucial to the success of an IT project, and also the company's 
capabilities in relation to factors such as IT readiness. Based on previous studies, it can be seen several factors related to IT Readiness for SMEs, as mentioned in table 2 [14].

TABLE 2: List of Factors related to IT Readiness.

\begin{tabular}{l|l}
\hline Characteristics & Factors From Literature \\
Organization & $\begin{array}{l}\text { 1. Suppliers, customers, competitors, government, IT } \\
\text { product vendors, and IT consultants }\end{array}$ \\
& 2. External pressures \\
3. Resources availability \\
4. Relative advantages and costs \\
1. Owner/manager knowledge \\
\hline 2. Individual characteristics \\
3. Existence of technology leaders and level of \\
technological education \\
4. Top management support \\
5. Management's direct and explicit support \\
1. Employee knowledge \\
2. Individual characteristics \\
$\begin{array}{l}\text { 3. Existence of technology leaders and level of } \\
\text { technological education }\end{array}$ \\
4. Employee attitude and employee acceptance
\end{tabular}

In organization-related characteristic, IT projects aim to gain competitive advantage or minimize gaps for competitors. In this context, IT can have the goal of delivering new services to customers or making the company more efficient [14]. Furthermore, in conjunction with suppliers and customers, IT can be used to improve transaction processing efficiency, better response times, reduced transaction costs, etc.

The second characteristic, related to management, limited knowledge of IT can be a barrier to IT implementation, although it may be sufficient knowledge of IT adoption and its organizational impacts to hinder management of IT projects [14]. In large companies, having IT projects managed by internal experts has an important role for IT adoption. However, SMEs often cannot afford to buy or attract competent employees adequately.

For the last characteristic, employees are related to IT skills, which can be linked to software technical skills or simply refer to the user's perspective. IT skills of SME employees have a positive impact with IT implementation [14]. It has been argued that employees tend to receive and support IT projects if they are confident of profit and are confident that they can use IT. Furthermore, training provided to employees also often positively impacts their attitudes towards IT systems and their use. In this context, it should be noted that SMEs often have difficulty in recruiting and retaining internal experts, inter alia, due to the limited career development opportunities in 
SMEs. Another aspect related to this is employee motivation, which is associated with the fear of losing a job and a reluctance to change the work routine.

In conjunction with the concept of the development of information technology made by an organization, in this study we also use the CMMI (Capability Maturity Model Integration) developed by Carnegie Melon University [15]. CMMI has five levels of maturity and process areas, as described in Table 3 [16]. The purpose of CMMI use in this study is to provide guidance on the development of information technology that is aligned with the development of the organization, so it is expected to know the level of IT readiness can be made development proposals that have a positive impact for SMEs.

Based on the description in Table 3 above, it can be seen that the maturity level consists of a set of process areas that have been determined. The maturity level is measured on the level of performance of the specific and general goals applicable to each set of designated process areas. Each level of maturity helps to establish the foundation needed for effective implementation of the next level. Higher level processes have a greater failure rate if they do not make suggested improvements by lower levels and the effect of innovation can be obscured in noisy processes. The process of achieving a higher level of maturity by an organization can be done with a lower due rate, but it risks not being consistently applied in a crisis [16].

\section{Research Methodology}

This study intends to obtain the condition of SMEs based on factors that influence the readiness of SMEs in adopting information technology, which is best suited to run the business. This research is a qualitative research conducted by using interview technique and questionnaire [17]. Sources of information in this study are SME business owners or people who know the business comprehensively, including entrepreneurs from various types of industries in which each industry is represented by several entities. The results of questionnaires are categorized and analyzed using descriptive statistical approach. The data in this study were obtained from SME associations from six counties in East Java, namely Pasuruan, Lamongan, Surabaya, Jember, Sidoarjo, Gresik, Malang and Jombang. Among the SMEs observed, all belong to the small business category. Their business is categorized as a micro business based on Law No.20 of 2008 on Micro, Small and Medium Enterprises [18], as listed in Table 4.

The number of SMEs obtained from the Office of Cooperatives and SMEs East Java Province has been included in Table 4 along with the number of samples used in this 
TABLE 3: Maturity Levels and Process Areas in CMMI [16].

\begin{tabular}{|c|c|c|c|}
\hline Level & Focus & Key Process Area & Result \\
\hline \multirow[t]{2}{*}{5 (Optimizing) } & $\begin{array}{l}\text { Continuous Process } \\
\text { Improvement }\end{array}$ & $\begin{array}{l}\text { 1. Organizational Innovation } \\
\text { and Deployment }\end{array}$ & $\begin{array}{l}\text { Highest Quality / } \\
\text { Lowest Risk }\end{array}$ \\
\hline & & $\begin{array}{l}\text { 2. Causal Analysis and } \\
\text { Resolution }\end{array}$ & \\
\hline \multirow[t]{2}{*}{$\begin{array}{l}4 \text { (Quantitatively } \\
\text { Managed) }\end{array}$} & $\begin{array}{l}\text { Quantitatively } \\
\text { Managed }\end{array}$ & $\begin{array}{l}\text { 1. Organizational Process } \\
\text { Performance }\end{array}$ & $\begin{array}{l}\text { Higher Quality / } \\
\text { Lower Risk }\end{array}$ \\
\hline & & $\begin{array}{l}\text { 2. Quantitative Project } \\
\text { Management }\end{array}$ & \\
\hline \multirow[t]{13}{*}{3 (Defined) } & $\begin{array}{l}\text { Process } \\
\text { Standardization }\end{array}$ & 1. Requirements Development & $\begin{array}{l}\text { Medium Quality / } \\
\text { Medium Risk }\end{array}$ \\
\hline & & 2. Technical Solution & \\
\hline & & 3. Product Integration & \\
\hline & & 4. Verification and Validation & \\
\hline & & 5. Organizational Process Focus & \\
\hline & & $\begin{array}{l}\text { 6. Organizational Process } \\
\text { Definition }\end{array}$ & \\
\hline & & 7. Organizational Training & \\
\hline & & $\begin{array}{l}\text { 8. Integrated Project } \\
\text { Management }\end{array}$ & \\
\hline & & 9. Risk Management & \\
\hline & & $\begin{array}{l}\text { 10. Decision Analysis and } \\
\text { Resolution }\end{array}$ & \\
\hline & & 11. Integrated Teaming & \\
\hline & & $\begin{array}{l}\text { 12. Org. Environment for } \\
\text { Integration }\end{array}$ & \\
\hline & & $\begin{array}{l}\text { 13. Integrated Supplier } \\
\text { Management }\end{array}$ & \\
\hline \multirow[t]{7}{*}{2 (Managed) } & $\begin{array}{l}\text { Basic Project } \\
\text { Management }\end{array}$ & 1. Requirements Management & $\begin{array}{l}\text { Low Quality / High } \\
\text { Risk }\end{array}$ \\
\hline & & 2. Project Planning & \\
\hline & & $\begin{array}{l}\text { 3. Project Monitoring and } \\
\text { Control }\end{array}$ & \\
\hline & & $\begin{array}{l}\text { 4. Supplier Agreement } \\
\text { Management }\end{array}$ & \\
\hline & & 5. Measurement and Analysis & \\
\hline & & $\begin{array}{l}\text { 6. Process and Product Quality } \\
\text { Assurance }\end{array}$ & \\
\hline & & 7. Configuration Management & \\
\hline 1 (Initial) & $\begin{array}{l}\text { Process is informal } \\
\text { and Adhoc }\end{array}$ & No Process Area & $\begin{array}{l}\text { Lowest Quality / } \\
\text { Highest Risk }\end{array}$ \\
\hline
\end{tabular}

study which is calculated with the help of online applications [19], with $95 \%$ confidence level and a margin of error of $5 \%$ for large population. The stages of the research conducted as a whole can be seen in Figure 2. 
TABle 4: Categories of Enterprise by Size of Assets and Turnover [18].

\begin{tabular}{l|c|c|}
\hline Category & Net Asset (IDR in Billion) & Turnover (IDR in Billion) \\
\hline Micro & $<0.05$ & $<0.3$ \\
\hline Small & $0.05-0.5$ & $0.3-2.5$ \\
\hline Medium & $0.5-10$ & $2.5-50$
\end{tabular}

TABLE 5: Number of SMEs and Samples of Each District.

\begin{tabular}{l|c|c|}
\hline Cities & Number of SMEs & $\begin{array}{c}\text { Estimated } \\
\text { Samples }\end{array}$ \\
\hline Pasuruan & 10,564 & 371 \\
\hline Lamongan & 8,535 & 368 \\
\hline Surabaya & 31,867 & 380 \\
\hline Sidoarjo & 14,836 & 374 \\
\hline Gresik & 9,569 & 369 \\
\hline Malang & 9,414 & 369 \\
\hline Jombang & 8,587 & 368 \\
\hline
\end{tabular}

The stage of identification and formulation of problem has been done in introduction section, which is measuring the level of information technology readiness and gap analysis to find out the current performance condition of SMEs. Then, at the stage of conducting literature studies has been explained in theoretical background section.
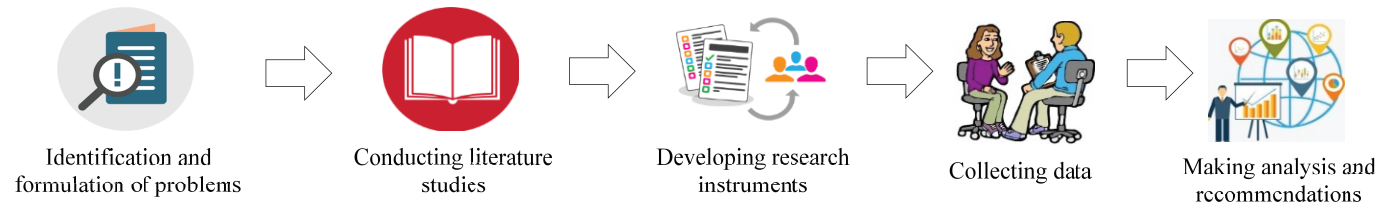

Figure 2: Staging Of Research Methodology.

In this study, the research instrument development phase, we designed an instrument that refers Parasuraman [20] as a base to conduct follow-up interviews with SMEs that we have chosen as an object of study. The list of instruments used in this study, namely:

1. Systems and information technology help business sustainability

2. Conveniences in using systems and information technology

3. Systems and information technology affect your life

4. Application of systems and information technology in your business

5. Ever interact with systems and information technology 
6. The influence of the environment influences your decision to use information technologies

7. Conducting personal communication through various modern telecommunication media

8. My business always supports the advancement of technology usage

9. System advances and information technology bring benefits to your business

10. Are you currently using information systems in your business? If yes or no, please explain your reasons!

11. When you decide to use information systems, how will you choose the right system for your business?

Furthermore, at the data gathering stage, we distributed questionnaires by visiting SME business locations to ensure that the questionnaire reached its destination because some SMEs had an uncertain address. After the respondents answered the questionnaire, we proceeded to the gap analysis stage and made recommendations for improvement in the next section.

\section{Result and Discussion}

Based on the results of the questionnaires we received (not all questionnaires returned according to the number of respondents) of SMEs, it can be classified into two groups of BPM maturity levels as shown in Table 5.

TABLE 6: Number of Returned Questionnaires from Each District.

\begin{tabular}{l|c|c|c|}
\hline County & $\begin{array}{c}\text { \# Returned } \\
\text { Questionnaire }\end{array}$ & \multicolumn{2}{|c|}{ BPM Maturity } \\
\cline { 3 - 4 } & Level 1 & Level 2 \\
\hline Pasuruan & 371 & 252 & 119 \\
\hline Lamongan & 368 & 272 & 96 \\
\hline Surabaya & 380 & 327 & 53 \\
\hline Sidoarjo & 374 & 325 & 49 \\
\hline Gresik & 369 & 284 & 85 \\
\hline Malang & 369 & 229 & 140 \\
\hline Jombang & 368 & 324 & 44 \\
\hline
\end{tabular}

In the interview process with SMEs, IT readiness results can be seen in Figure 3, but not all SME owners have plans to improve the level of maturity of their business 
processes, as shown in Figure 4. Basically, SME owners have realized the importance of using information technology as a tool that supports their business activities, though with an emphasis on a few different things on which to base decision-making in the use of information technology or not. The key point in making the decision to use information technology is different among SME owners.

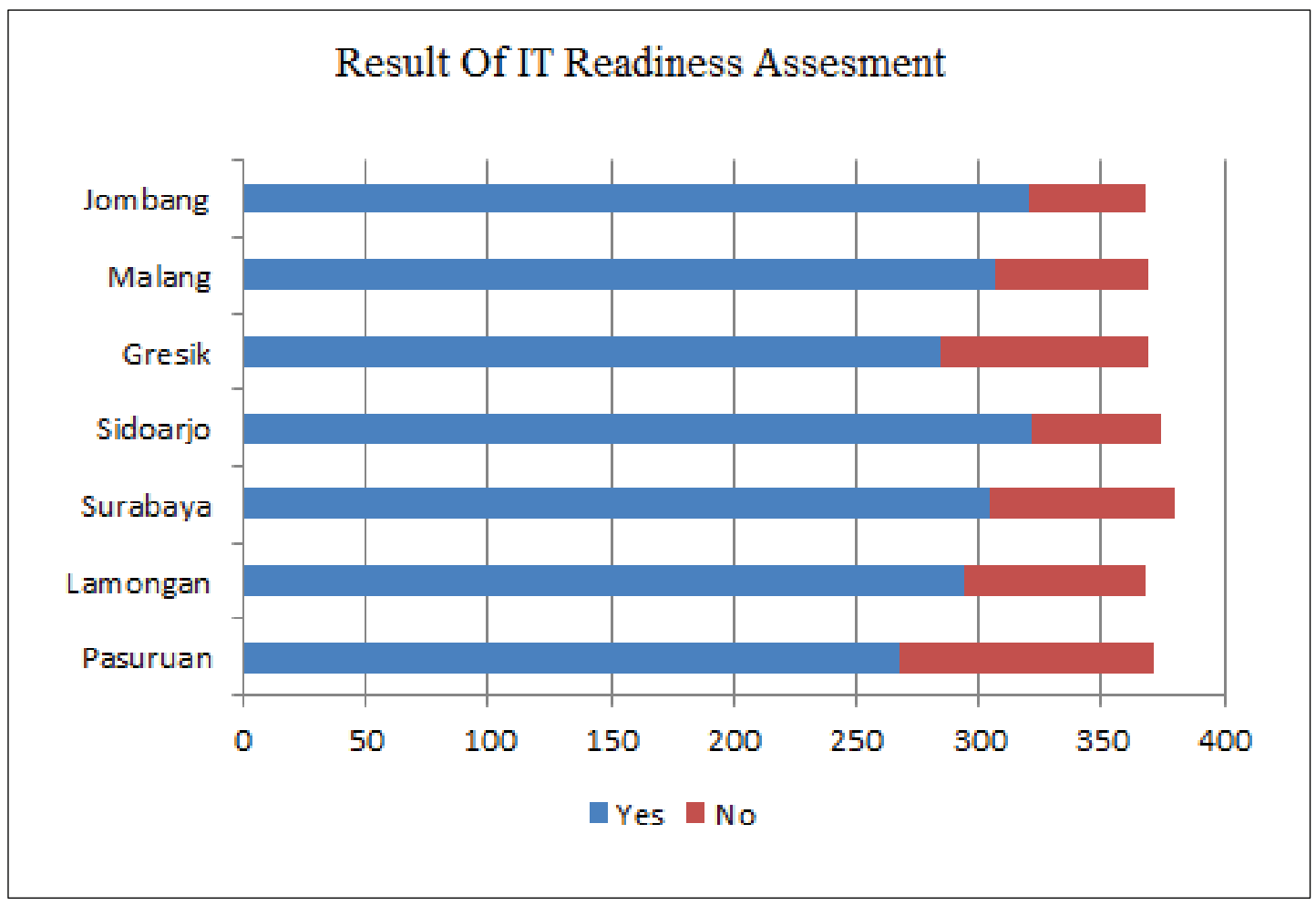

Figure 3: The Result of Information Technology Readiness Assessment for SMEs.

Furthermore, we conducted an analytical gap based on BPMM level and CMMI as per the objectives of achieving each level and providing recommendations on IT-based solutions, as listed in Table 6.

The explanation of goal and IT solution relationships is as follows: business demand is focused on efficiency and often frustrates IT leaders, who can look around the company and see many opportunities for cross-functional processes and collaboration. Level 1 processing is intended for transaction processing and basic operational data solutions with the overall goal of reducing the cost of doing business. At Level 2, business demand evolves from a focus on business efficiency to effectiveness. The business processes in this level also included handling enterprise integration and consolidated management information. Supply from level 2 is aimed at deploying public infrastructure and enterprise systems, including 'IT as a business' with attention to portfolio management, service management, and faster deliverables. 


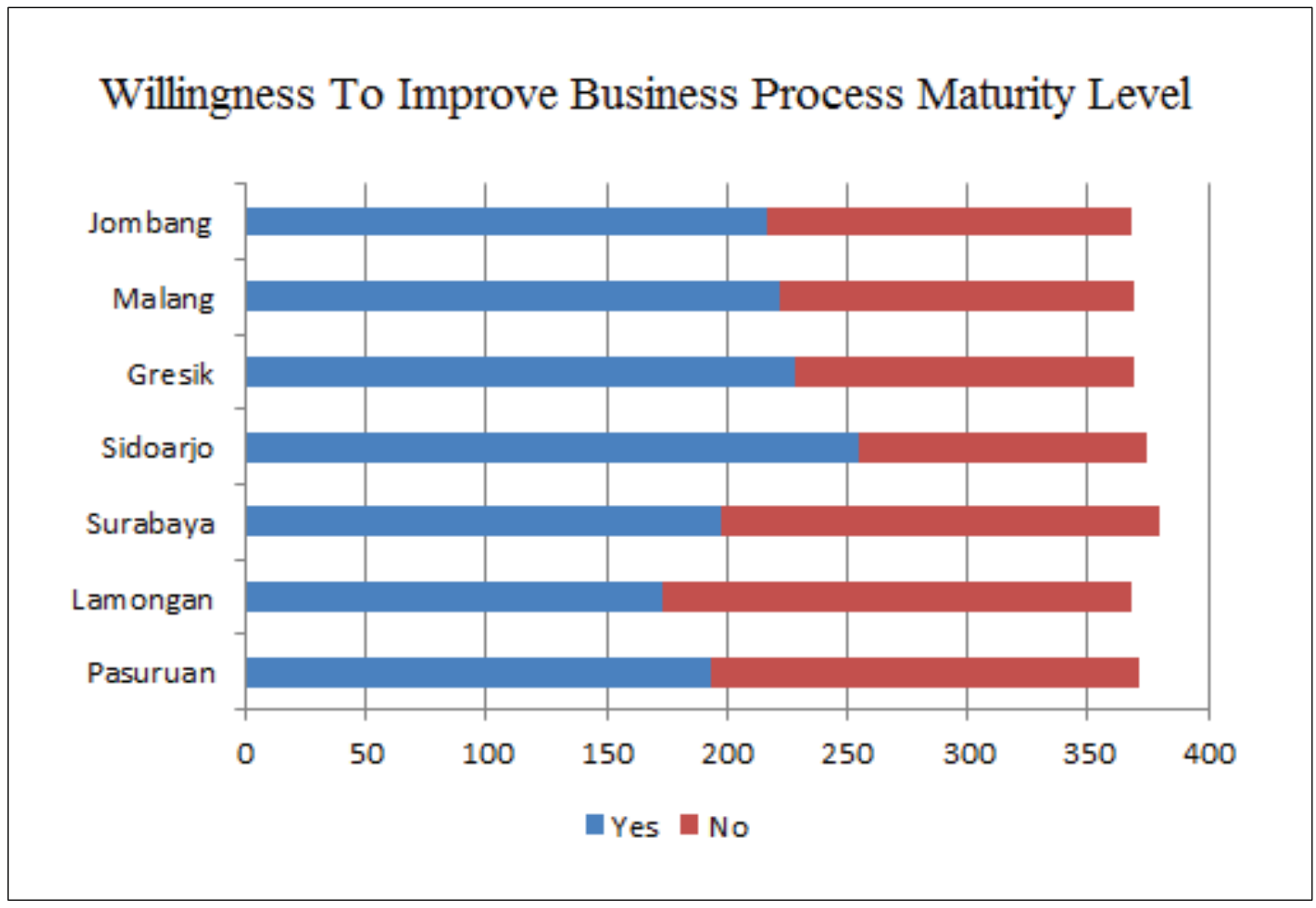

Figure 4: The Eagerness of SME Owners to Improve Business Process Maturity.

Request Level 3 (which is in addition to Level 1 and 2 requests) usually addresses the growth and innovation of businesses that support IT. At this level, business demand shifts in focus from effectiveness to innovation and growth. There is a tendency to focus more externally than the lower Level, attracted to business intelligence, experimentation and quick collaboration - both with other business units as well as with customers and suppliers.

\section{Conclusion}

Based on the results outlined earlier, the first thing to conclude is that there are certain considerations for SME owners to use or not to use information technology. This is in fact not determined by the success of competitors who have applied information technology but are influenced by personal experience. Not every business entity will use information technology, although they have stated that the adoption of information technology is quite important.

The second conclusion is that moving from Level 1 to 2 requires mastery in the areas of project management and service, as it is in CMMI, whereas from an IT-based solution point of view. To achieve Level 2, SMEs can recruit human resources with the requirements to master the program, portfolio, and product management. Transition Level 1 
TABLE 7: Gap analysis and IT-based solutions to achieve goals

\begin{tabular}{|c|c|c|c|c|c|}
\hline \multirow{2}{*}{$\begin{array}{l}\text { BPMM \& } \\
\text { CMMI }\end{array}$} & \multirow[t]{2}{*}{ Goal(s) } & \multicolumn{3}{|c|}{ Gap Analysis } & \multirow[t]{2}{*}{ IT Solution } \\
\hline & & Organization & Management & Employee & \\
\hline \multirow[t]{3}{*}{ Level 1} & $\begin{array}{l}\text { Business } \\
\text { Efficiency }\end{array}$ & $\begin{array}{l}\text { The need to build } \\
\text { a basic system }\end{array}$ & $\begin{array}{l}\text { The need for } \\
\text { increasing } \\
\text { knowledge of the } \\
\text { owner or } \\
\text { manager }\end{array}$ & $\begin{array}{l}\text { The importance } \\
\text { of increasing } \\
\text { knowledge and } \\
\text { skills of } \\
\text { employees by } \\
\text { using IT }\end{array}$ & $\begin{array}{l}\text { business process } \\
\text { improvement }\end{array}$ \\
\hline & & $\begin{array}{l}\text { Provides } \\
\text { information for } \\
\text { business } \\
\text { operations }\end{array}$ & $\begin{array}{l}\text { The importance } \\
\text { of top } \\
\text { management } \\
\text { awareness to } \\
\text { understand the } \\
\text { use of IT as an } \\
\text { enabler }\end{array}$ & $\begin{array}{l}\text { the importance of } \\
\text { employee } \\
\text { awareness to } \\
\text { accept the use of I }\end{array}$ & $\begin{array}{l}\text { operational } \\
\text { stabilization and } \\
\text { business support }\end{array}$ \\
\hline & & $\begin{array}{l}\text { Oriented to the } \\
\text { business function }\end{array}$ & $\begin{array}{l}\text { the need for } \\
\text { management } \\
\text { support in } \\
\text { improving the } \\
\text { process and } \\
\text { implementation } \\
\text { of IT }\end{array}$ & & $\begin{array}{l}\text { developing } \\
\text { applications for } \\
\text { basic services }\end{array}$ \\
\hline \multirow[t]{3}{*}{ Level 2} & $\begin{array}{l}\text { Business } \\
\text { Effectiveness }\end{array}$ & $\begin{array}{l}\text { The importance } \\
\text { of building } \\
\text { partnerships }\end{array}$ & $\begin{array}{l}\text { The need to } \\
\text { recruit human } \\
\text { resources who } \\
\text { have the ability to } \\
\text { manage IT }\end{array}$ & $\begin{array}{l}\text { The need to } \\
\text { provide an } \\
\text { understanding to } \\
\text { employees in } \\
\text { terms of receiving } \\
\text { IT }\end{array}$ & $\begin{array}{l}\text { doing } \\
\text { infrastructure } \\
\text { improvements }\end{array}$ \\
\hline & & $\begin{array}{l}\text { Build } \\
\text { consolidation of } \\
\text { information } \\
\text { management }\end{array}$ & $\begin{array}{l}\text { The need for } \\
\text { management } \\
\text { support in the } \\
\text { implementation } \\
\text { of business } \\
\text { process } \\
\text { improvement }\end{array}$ & $\begin{array}{l}\text { The need to } \\
\text { provide training } \\
\text { to employees to } \\
\text { improve the } \\
\text { culture or } \\
\text { behavior in the } \\
\text { organization }\end{array}$ & $\begin{array}{l}\text { to improve } \\
\text { service }\end{array}$ \\
\hline & & $\begin{array}{l}\text { Doing business } \\
\text { process } \\
\text { integration }\end{array}$ & & & $\begin{array}{l}\text { build credibility in } \\
\text { the use of IT }\end{array}$ \\
\hline \multirow[t]{3}{*}{ Level 3} & $\begin{array}{l}\text { doing business } \\
\text { transformation }\end{array}$ & $\begin{array}{l}\text { Utilization of } \\
\text { business } \\
\text { intelligence }\end{array}$ & $\begin{array}{l}\text { developing } \\
\text { flexible and agile } \\
\text { business skills }\end{array}$ & same as above & $\begin{array}{l}\text { using open } \\
\text { platform to build } \\
\text { collaboration with } \\
\text { other parties }\end{array}$ \\
\hline & & $\begin{array}{l}\text { Business growth } \\
\text { by creating of } \\
\text { new fields }\end{array}$ & $\begin{array}{l}\text { developing } \\
\text { inter-enterprise } \\
\text { solutions }\end{array}$ & & $\begin{array}{l}\text { realizing company } \\
\text { values }\end{array}$ \\
\hline & & $\begin{array}{l}\text { Collaborate with } \\
\text { others and } \\
\text { innovate }\end{array}$ & & & $\begin{array}{l}\text { converging } \\
\text { business and IT } \\
\text { functions }\end{array}$ \\
\hline
\end{tabular}

to 2 requires the ability of a strong IT architecture, because there are prerequisites for the fulfillment of physical and logical technology architecture. This is consistent with the IT solutions listed in Table 6. Meanwhile, if there is an increase to level 3 demands 
different kinds of IT capabilities delivering different types of services in different forms of partnership between business and IT.

\section{References}

[1] Office of Cooperatives and SMEs of East Java Province, "Dinas Koperasi Dan UMKM Provinsi Jawa Timur," 5 March 2011. [Online]. Available: http://diskopukm.jatimprov. go.id/. [Accessed 20 April 2018].W430W9967

[2] R. Skrinjar and P. Trkman, "Increasing process orientation with business process management:Critical practices," International Journal of Information Management, vol. 33, no. 1, pp. 48-60, 2013. W430W9967

[3] K. McCormack, J. Wiliems, J. V. D. Berg, D. Deschoolmeester, P. Wilaert, M. I. Stemberger, R. Skrinjar, P. Turkman, B. M. Ladeira, M. P. V. D. Oliveira, V. B. Vuksic and N. Vlahovic, "A global investigation of key turning points in business process maturity," Business Process Management Journal, vol. 15, no. 5, pp. 792-815, 2009. W430W9967

[4] C. Ranganathan and J. S. Dhaliwal, "A survey of business process reengineering practices in Singapor," Information And Management, vol. 39, no. 2, pp. 125-134, 2001. W430W9967

[5] Q. Zhang and M. Cao, "Business Process Reengineering For Flexibility And Innovation In Manufacturing," Industrial Management \& Data Systems, vol. 102, no. 3, pp. 146-152, 2002. W430W9967

[6] N. Abdi, B. Zarei, J. Vaisy and B. Parvin, "Innovation Models and Business Process Redesign," International Business and Management, vol. 3, no. 2, pp. 147-152, 2011. W430W9967

[7] M. Okręglicka, M. Mynarzová and R. Kaňa, "Business Process Maturity In Small And Medium-Sized Enterprises," Polish Journal Of Management Studies, vol. 12, no. 1, pp. 121-132, 2015. W430W9967

[8] J. Kalina, Z. Smutny and V. Řezníček, "Business Process Maturity as a Case of Managerial Cybernetics and Effective Information Management," in European Conference on Information Management and Evaluation, Sopot, Poland, 2013. W430W9967

[9] A. V. Looy, M. D. Backer and G. Poels, "Defining business process maturity. A journey towards excellence," Total Quality Management \& Business Excellence, vol. 22, no. 11, pp. 1119-1137, 2011. W430W9967 
[10] D. E. Harter, M. S. Krishnan and S. A. Slaughter, "Effects of Process Maturity on Quality, Cycle Time, and Effort in Software Product Development," Journal Management Science, vol. 46, no. 4, pp. 451-466, 2000. W430W9967

[11] LEADing Practise, "BPM Handbook - Maturity Model," LEADing Practice, 30 Sept 2015. [Online]. Available: www.bpmhandbook.com. [Accessed 15 May 2018].W430W9967

[12] C. Păunescu and C. Acatrinei, "Managing maturity in process-based improvement organizations: a perspective of the Romanian companies," Journal of Business Economics and Management, vol. 13, no. 2, pp. 223-241, 2012. W430W9967

[13] The Object Management Group, Business Process Maturity Model, Massachusetts, USA: The Object Management Group, 2008. W430W9967

[14] A. Haug, S. G. Pedersen and J. S. Arlbjørn, "IT readiness in small and medium-sized enterprises," Industrial Management and Data, vol. 111, no. 4, pp. 490-508, 2011. W430W9967

[15] M. C. Paulk, "A History of the Capability Maturity Model for Software," in The Software Quality Profile, Atlanta, GA, ASQ, 2010, Pp. 5-19.W430W9967

[16] Tutorials Point, "CMMI Maturity Levels," Tutorials Point, 08 February 2014. [Online]. Available: http://www.tutorialspoint.com/cmmi/cmmi-maturity-levels. htm. [Accessed 20 May 2018].W430W9967

[17] R. K. Yin, Case Study Research and Applications: Design and Methods, California: SAGE Publication Inc., 2017. W430W9967

[18] Kementerian Hukum Dan HAM Republik Indonesia, Undang-Undang Nomor 20 Tahun 2008 Tentang Usaha Mikro, Kecil Dan Menengah, Jakarta: Kementerian Sekretariat Negara Republik Indonesia, 2008. W430W9967

[19] Creative Research Systems, "Sample Size Calculator," Creative Research Systems, 2012. [Online]. Available: https://www.surveysystem.com/sscalc.htm\#one. [Accessed o5 May 2018].W430W9967

[20] A. Parasuraman and C. L. Colby, "An Updated and Streamlined Technology Readiness Index: TRI 2.0," Journal of Service Research, Pp. 1-16, 2014. W430W9967 